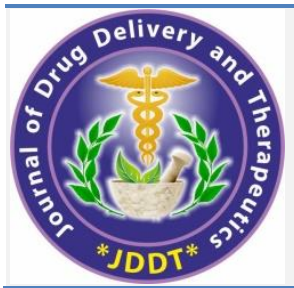

Open Access Full Text Article
Available online on 15.08.2021 at http://jddtonline.info

\section{Journal of Drug Delivery and Therapeutics}

Open Access to Pharmaceutical and Medical Research

Copyright (c) 2021 The Author(s): This is an open-access article distributed under the terms of the CC BY-NC 4.0 which permits unrestricted use, distribution, and reproduction in any medium for non-commercial use provided the original author and source are credited

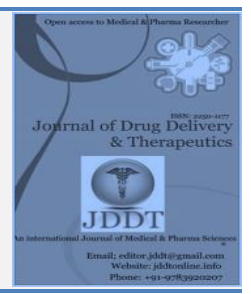

Research Article

\title{
Biochemical profile of Boswellia serrata and Rhus mysorensis
}

\author{
U.B. Kadam ${ }^{1 *}$, K.M. Khalkar2, (DV.B. Kadam*2 \\ ${ }^{1}$ Principal and Head, Department of Chemistry, Samajshree Prashant Dada Hire Arts, Comm. \& Science College, Nampur, Malegaon (Nashik), India \\ 2 P.G. Department of Botany and Research Centre, M.V.P Samaj's K.T.H.M. College, Nashik, 422002 (M.S.) India
}

Article Info:
Cite this article as:
Kadam UB, Khalkar KM, Kadam VB, Biochemical
profile of Boswellia serrata and Rhus mysorensis,
Journal of Drug Delivery and Therapeutics. 2021;
11(4-S):131-133
$\begin{aligned} & \text { DoI: } h \text { ttp://dx.doi.org/10.22270/jddt.v11i4-S.4975 } 26 \text { July } 2021 \\ & \text { Published 15 August } 2021\end{aligned}$

\section{Abstract}

The seasonal variation of proteins and amino acids content have been investigated from leaves, wood and bark of Boswellia serrata and Rhus mysorensis are the medicinal important plant of Laling forest Dhule district of Maharashtra. Comparative account of protein content of leaves, wood and bark of Rhus mysorensis showed higher level (range 1.897 to $2.754 \mathrm{mg} / \mathrm{g}$ dry wt.) than Boswellia serrata (range 1.846 to $2.312 \mathrm{mg} / \mathrm{g}$ dry/wt.). Comparative account of amino acid content of leaves, wood and bark of Rhus mysorensis showed higher level (range 0.911 to $1.074 \mathrm{mg} / \mathrm{g}$ dry wt.) than Boswellia serrata (range 0.745 to $0.896 \mathrm{mg} / \mathrm{g}$ dry wt.).

Keywords: Protein, amino acid , Boswellia serrata and Rhus mysorensis

*Address for Correspondence: U.B. Kadam, Principal and Head, Department of Chemistry, Samajshree Prashant Dada Hire Arts, Comm. \& Science College, Nampur, Malegaon (Nashik), India

\section{INTRODUCTION}

India has one of the oldest, richest and most diverse cultural traditions associated with the use of medicinal plants as medicine like Ayurveda, Siddha, Unani and the Tibetan systems ${ }^{1}$. Indian economy depends greatly on the number of wild plant species. The forest of Maharashtra covers a hugs area of $61.939 \mathrm{sq} \mathrm{km}$. thus covering about $21 \%$ of the total land. The forest of Dhule district covers an area of 209 thousand Hectors which is $28.5 \%$ of the total state area. In the present study of plant diversity of Laling forest situated in Dhule district. Laling forest area has spread over 4200 hectors. The Laling forest spread around the Laling fort and situated 9.65 kilometers away from Dhule city. The forest area around the Laling fort having rich plant diversity. Many medicinal plants, herbs, shrubs, climbers and evergreen trees spread Laling forest around the Laling fort. Medicinal plants have been used as traditional treatments for numerous human diseases for thousands of years. Since time immemorial, plants and their products have been the primary resource of food, shelter, clothing, flavors, and fragrances as also valuable ingredients for medicines for mankind. In this context, natural resins have played an important role. These have also been used as adhesives, as ingredients for cosmetic preparations, as fragrances in daily rituals and in religious ceremonies, as coating materials and also for their different curative powers ${ }^{2,3}$.

In ancient times, Hindus, Babylonians, Persians, Romans, Chinese and Greeks as well as the people of old American civilizations used natural resins primarily for embalming and for its incense in cultural functions. They firmly believed that when these materials get in contact with fire, the smoke and the fragrance they produce not only soothe their souls but also please their gods. Burning of these natural resins had become an important component of their cultural life. They burned these resins during sacrificial ceremonies and in their daily rituals to prevent the influence of evil spirits on their souls or to honour the dead or living ones ${ }^{4,5}$. Boswellia serrata (Salai/Salai guggul) (Family: Burseraceae; Genus: Boswellia) is a moderate to large sized branching tree that grows in dry mountainous regions of India, Northern Africa and the Middle East ${ }^{6,7}$. Since ancient times, three of these species have been considered as 'true Frankincense' producing trees ${ }^{8}$.

In addition to its beneficial use for arthritis, this gummy resin is also mentioned in traditional Ayurvedic and Unani texts as an effective remedy for diarrhoea, dysentery, ringworm, boils, fevers (antipyretic), skin and blood diseases, cardiovascular diseases, mouth sores, bad throat, bronchitis, asthma, cough, vaginal discharges, hair-loss, jaundice, hemorrhoids, syphilitic diseases, irregular menses and stimulation of liver. It is also diaphoretic, astringent, and diuretic and acts both as internal and external stimulant. Modern medicine and pharmacology strongly point out to its use as an antiarthritic, antiinflammatory, antihyperlipidemic (controls blood lipids), antiatherosclerotic (anticoronary plaque), analgesic (pain-reliever) and hepatoprotective (protects the liver) ${ }^{9,10}$.

The plant Rhus mysorensis is known to possess various active constituents like steroids, alkaloids, flavonoids, glycosides, tannins and Phenols. The plant is screened for 
hepatoprotective, anti-diabetic, hypolipidemic, antimicrobial and anti-oxidant activity. The increasing demand of plant extracts to use in the cosmetic, food and pharmaceutical industries suggests that systematic studies of medicinal plants are very important in order to find active compounds and their use as a medicine for curing various diseases ${ }^{11}$. According to World Health Organization, medicinal plants would be the best source to obtain a variety of drugs. Therefore, such plants should be investigated to better understand their properties, safety and efficacy ${ }^{12}$. Rhus mysorensis is one among such medicinal traditionally used plants. Fruits are used to treat Dysentery; Leaf decoction is given in itching ${ }^{13}$. Leaves given in Diarrhea and Stomatitis, Leaf paste rubbed against rash and allergy ${ }^{14}$. The root, stem and leaf are traditionally used in treatment of diabetes ${ }^{15}$, famine periods, plant extracts for protection against HSV2 infection, Immune-modulating properties, Antifertility Psoriasis ${ }^{16}$, Psoriasis ${ }^{17}$.

The phytochemical constituents and medicinal properties of most of the medicinal plants were recorded in the last few decades by a number of workers ${ }^{18,19}$. These medicinal plants are subjected to various processes and are then administrated to the patients. The survey and documentation of medicinally important plants in each and every place is very much important for easy identification of local traditional healers, conservation and sustainable utilization. Plants have always played a major role in the treatment of human traumas and diseases worldwide. They have been used as sources of modern drugs, either by providing pure compounds, starting materials for partial synthesis of useful compounds or models for synthesis of new drugs. According to the World Health Organization (WHO) as much as $80 \%$ of world's population depends on traditional medicine for their primary health care needs ${ }^{20}$.

\section{MATERIALS AND METHOD}

1) Quantitative estimation of Protein: The protein was quantitatively estimated by the Lowry et.al., 1951 method .

Chemicals: 1) $0.1 \% \mathrm{~N} \mathrm{NaOH}-(4 \mathrm{gm}$ in $1000 \mathrm{ml})$

2) $2 \% \mathrm{Na}_{2} \mathrm{CO}_{3}$ (2 gm in $100 \mathrm{ml}$ distilled water)

3) $0.5 \% \mathrm{CuSO}_{4}$ (0.5 gm in $100 \mathrm{ml}$ distilled water)

4) $1 \% \mathrm{Na}-\mathrm{K}$ tartarate

5) $5 \%$ Trichloro acetic acid /per Chloric acid

Reagents: 1) Lowry A-2\% $\mathrm{Na}_{2} \mathrm{CO}_{3}$ in $0.1 \% \mathrm{~N} \mathrm{NaOH}$

2) Lowry $\mathrm{B}-5 \% \mathrm{CuSO} 4$ in $1 \% \mathrm{Na}-\mathrm{K}$ tartarate

3) Lowry C-98 $\mathrm{ml} \mathrm{A}$ and $2 \mathrm{ml} \mathrm{B}$,

4) Lowry D- Folin phenol reagent.

Procedure: $1 \mathrm{gm}$ of plant material was homogenized with 10 $\mathrm{ml} 80 \%$ ethanol. The extract was centrifuged at $5000 \mathrm{rpm}$. For 5 minute and the supernatant was discarded $5 \% 10 \mathrm{ml}$ Trichloro acetic acid (TCA) or per chloric acid (PCA) was add to residue and incubated at $80^{\circ} \mathrm{C}$ for 20 minutes. The pellet was centrifuged and the supernatant was discarded. Residue was washed with $10 \mathrm{ml}$ distilled water and again recentrifuged. The supernatant was discarded $2 \% 10 \mathrm{ml}$ $\mathrm{Na}_{2} \mathrm{CO}_{3}$ in $0.1 \mathrm{~N} \mathrm{NaOH}$ was added to the residue and incubated for an hour at $30^{\circ} \mathrm{C}$ and again centrifuged and residue was discarded. The final volume of supernantant was measured and it was used as a sample for protein. $1 \mathrm{ml}$ of aliquot of sample was taken and $5 \mathrm{ml}$ reagent $\mathrm{C}$ was added to it mixed it thoroughly. The sample was incubated for 10 minutes and $1 \mathrm{ml}$ of reagent $\mathrm{D}$ was added to it. The colour intensity was read at $660 \mathrm{~nm}$ using Spectrophotometer. The protein concentration of an unknown sample was calculated using standard graph.

\section{2) Quantitative estimation of total Amino Acid:}

Estimation of total amino acid was carried out by Krishnamurthy et. al., 1989 method.

Reagents: 1) Alcoholic ninhydrin. (100 ml alcohol + $400 \mathrm{mg}$ ninhydrin)

2) Glycine (std.) (10 mg glycine $+100 \mathrm{ml}$ distilled water)

Procedure: $500 \mathrm{mg}$ plant material was ground in mortar and pestle with few drops of cold $80 \%$ ethanol. Then $2.5 \mathrm{ml}$ of distilled water and $10 \mathrm{ml}$ of boiling $80 \%$ ethanol were add to it. The extract was centrifuged for 15 minutes at 1,000 rpm. Residue was discarded the supernatant was collected and total volume was made $15 \mathrm{ml}$ with distilled water. Test tube was kept $60^{\circ} \mathrm{C}$ for 20 minutes. The test tube was cooled and $1 \mathrm{ml} \mathrm{50 \%}$ ethanol was added. Read at $420 \mathrm{~nm}$ in spectrophotometer. Glycine was used as stand rand.

\section{RESULTS AND DISCUSSION}

1) Boswellia serrata- The continuous two year investigation showed that the seasonal variation in protein content of leaves are (range from 2.467 to $2.754 \mathrm{mg} / \mathrm{g}$ dry wt.), higher level of proteins observed at summer 2.754 $\mathrm{mg} / \mathrm{g}$ dry wt. as compared to winter 2.557 and monsoon $2.467 \mathrm{mg} / \mathrm{g}$ dry wt.. In wood it was observed that at summer $2.292 \mathrm{mg} / \mathrm{g}$ dry wt. of protein accumulates and are higher than winter i.e. $2.265 \mathrm{mg} / \mathrm{g}$ dry wt. and monsoon $2.186 \mathrm{mg} / \mathrm{g}$ dry wt. The protein found in the bark ( range from 1.897 $\mathrm{mg} / \mathrm{g}$ dry wt. to $2.087 \mathrm{mg} / \mathrm{g}$ dry wt.), higher level observed in summer $2.087 \mathrm{mg} / \mathrm{g}$ dry wt. as compared to winter 1.990 $\mathrm{mg} / \mathrm{g}$ dry wt. and monsoon $1.897 \mathrm{mg} / \mathrm{g}$ dry wt.. The percentage of protein were found to be increasing order of leaves $<$ wood $<$ bark.

The amino acids ranges of leaves show from $0.993 \mathrm{mg} / \mathrm{g}$ dry wt. to $1.074 \mathrm{mg} / \mathrm{g}$ dry wt. highest level observed at summer season i.e. $1.074 \mathrm{mg} / \mathrm{g}$ dry wt. as compared to winter i.e. $1.032 \mathrm{mg} / \mathrm{g}$ dry wt. and monsoon $0.993 \mathrm{mg} / \mathrm{g}$ dry wt.. In wood amino acids accumulation observed high at summer $1.013 \mathrm{mg} / \mathrm{g}$ dry wt. as compared to winter i.e. $0.954 \mathrm{mg} / \mathrm{g}$ dry wt. and monsoon i.e. $0.917 \mathrm{mg} / \mathrm{g}$ dry wt. The amino acids accumulation in leaves show higher than wood and bark. Bark show higher accumulation of amino acids at summer $0.943 \mathrm{mg} / \mathrm{g}$ dry wt. than winter $0.923 \mathrm{mg} / \mathrm{g}$ dry wt. and monsoon $0.911 \mathrm{mg} / \mathrm{g}$ dry wt. The concentration of amino acids were found to be increasing order of leaves < wood<bark (Table No. 1; Graph No. 1).

2) Rhus mysorensis- The protein content of leaves show ranges from 2.166 to $2.312 \mathrm{mg} / \mathrm{g}$ dry wt. much more observed in summer $2.312 \mathrm{mg} / \mathrm{g}$ dry wt. than in winter $2.235 \mathrm{mg} / \mathrm{g}$ dry wt. and in monsoon $2.166 \mathrm{mg} / \mathrm{g}$ dry wt. In wood highest level protein observed at summer $2.187 \mathrm{mg} / \mathrm{g}$ dry wt. as compared to winter $2.123 \mathrm{mg} / \mathrm{g}$ dry wt. and monsoon $2.067 \mathrm{mg} / \mathrm{g}$ dry wt., while in bark proten accumulated much more in summer $2.011 \mathrm{mg} / \mathrm{g}$ dry wt. than winter $1.964 \mathrm{mg} / \mathrm{g}$ dry wt. and monsoon $1.846 \mathrm{mg} / \mathrm{g}$ dry wt. The percentage of protein were found to be increasing order of leaves $<$ wood $<$ bark.

The amino acid content of leaves showed higher than wood and bark. In leaves, amino acid ranges from $0.823 \mathrm{mg} / \mathrm{g}$ dry wt. to $0.896 \mathrm{mg} / \mathrm{g}$ dry wt., higher accumulation of amino acid observed at summer $0.896 \mathrm{mg} / \mathrm{g}$ dry wt. than winter 0.865 $\mathrm{mg} / \mathrm{g}$ dry wt. and monsoon $0.823 \mathrm{mg} / \mathrm{g}$ dry wt. The range of amino acid content of wood was between $0.811 \mathrm{mg} / \mathrm{g}$ dry wt. to $0.854 \mathrm{mg} / \mathrm{g}$ dry wt., it show lower than leaves. Higher level observed at summer i.e. $0.854 \mathrm{mg} / \mathrm{g}$ dry wt. as compared to winter $0.823 \mathrm{mg} / \mathrm{g}$ dry wt. and monsoon 0.811 $\mathrm{mg} / \mathrm{g}$ dry wt., while in bark, higher accumulation of amino acid observed at summer $0.801 \mathrm{mg} / \mathrm{g}$ dry wt. than in winter $0.787 \mathrm{mg} / \mathrm{g}$ dry wt. and monsoon $0.745 \mathrm{mg} / \mathrm{g}$ dry wt. 
Table 1: Seasonal variation of proteins and amino acids levels of different plants parts of Boswellia serrata and Rhus mysorensis

\begin{tabular}{|l|l|l|l|l|c|}
\hline \multirow{2}{*}{ PLANT PARTS } & \multirow{2}{*}{ SEASON } & \multicolumn{2}{|c|}{$\begin{array}{c}\text { PROTEINS } \\
\text { (Mg/g dry. wt.) }\end{array}$} & \multicolumn{2}{c|}{$\begin{array}{c}\text { AMINO ACIDS } \\
\text { (Mg/g dry.wt.) }\end{array}$} \\
\cline { 3 - 6 } & & Plant 1 & Plant 2 & Plant 1 & Plant 2 \\
\hline \multirow{3}{*}{ Leaves } & Summer & 2.754 & 2.312 & 1.074 & 0.896 \\
\cline { 2 - 6 } & Monsoon & 2.467 & 2.166 & 0.993 & 0.823 \\
\cline { 2 - 6 } & Winter & 2.557 & 2.235 & 1.032 & 0.865 \\
\hline \multirow{3}{*}{ Wood } & Summer & 2.292 & 2.187 & 1.013 & 0.854 \\
\cline { 2 - 6 } & Monsoon & 2.186 & 2.067 & 0.917 & 0.811 \\
\cline { 2 - 6 } & Winter & 2.265 & 2.123 & 0.954 & 0.823 \\
\hline \multirow{3}{*}{ Bark } & Summer & 2.087 & 2.011 & 0.943 & 0.801 \\
\cline { 2 - 6 } & Monsoon & 1.897 & 1.846 & 0.911 & 0.923 \\
\cline { 2 - 6 }
\end{tabular}

Plant 1 - Boswellia serrata Plant 2 - Rhus mysorensis

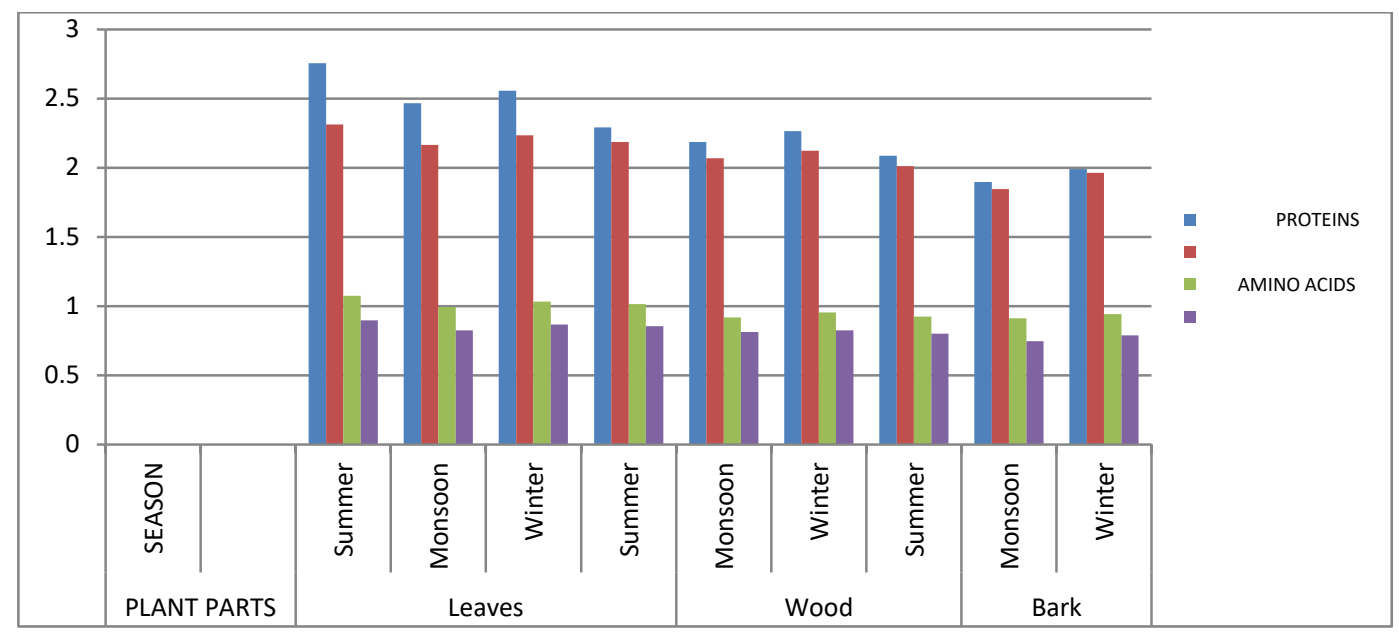

Graph 1: Seasonal variation of proteins and amino acids levels of different plants parts of Boswellia serrata and Rhus mysorensis

\section{REFERENCES}

1) Retnam, KR and Martin P. Ethnomedicinal Plants. Agrobios (India), Jodhpur. $2006 ; 05$

2) Felter H, Lloyd J. I and II. Cincinnati: Ohio Valley Company, US; Kings American Dispensatory. 1898.

3) Howes FN. Age-old resins of the Mediterranean region and their uses. Econ Bot.1950; 4:307-16. https://doi.org/10.1007/BF02985086

4) Krishnamurthy T, Shiva MP. Salai guggul (from Boswellia serrata Roxb.): Its exploitation and utilization. Indian Forest.1979; 103:466-74.

5) Verghese J. Olibanum in focus. Perfumer Flavorist.1998; 13:2-11

6) Maupetit P.New constituents in olibanum resinoid and essential oils. Perfumer Flavorist.1984; 9:19-37.

7) Leung AY, Foster S. New York: John Wiley and Sons. Encyclopedia of common natural ingredients used in food, drugs and cosmetics 1996; pp. 389-91.

8) Wallis TE. London: J and A Churchill Limited; . Textbook of Pharmacognosy. 1967; pp. 500-1

9) Sharma S, Thawani V, Hingorani L. Pharmacokinetic study of 11keto-beta-boswellic acid. Phytomedicine. 2004; 11:255-60. https://doi.org/10.1078/0944-7113-00290

10) Mathe C, Culioli G, Archier P. Characterization of archeological frankincense by gas chromatography mass spectrometry. J Chromatogr. 2004; 1023:277-85.

https://doi.org/10.1016/j.chroma.2003.10.016

11) Devesh Tewari HK, Pandey Sah AN, Meena HS, Manchanda A. Pharmacognostical and biochemical investigation of Ocimum kilimandscharicum plants available in western Himalayan region. Asian Journal of Plant Science and Research. 2012; 2(4):446-451
12) Doughari JH, El-mahmood AM, Tyoyina. Antimicrobial activity of leaf extracts of Senna obtusifolia (L). African Journal of Pharmacy and Pharmacology. 2008; 2(1):007- 013.

13) Priti MD, Yadav SR. Medicinal plants of South Western Maharashtra. In: Pullaiah T (Ed) Biodiversity in India. 1st Ed. Regency publications, New Delhi IV. 2006;180-181

14) Umberto Quattrocchi FLS. CRC World Dictionary of Medicinal and Poisonous plants. Common names, scientific names, Eponyms, Synonyms and Etymology. Published by CRC Press Taylor \& Francis Group.2012; 3211-3212.

15) Madhava Chetty K, Sivaji K, Tulasi Rao K. Flowering plants of Chittoor District Andhra Pradesh India. Student Offset Printers, Tirupati. 2008; 76.

16) Jeevan Ram A, Reddy RV, Adharvana M, Chari R, Venkata Raju. Rare and Little Known Medicinal Plants from Nallamalais of the Eastern Ghats, India. Journal of Plant Sciences. 2007; 2:113-117. https://doi.org/10.3923/jps.2007.113.117

17) Venkata Subbaiah KP, Savithramma N. Bio-Prospecting And Documentation Of Traditional Medicinal Plants Used To Treat Itching, Psoriasis And Wounds By Ethnic Groups Of Kurnool District, Andhra Pradesh, India. Asian Journal of Pharmaceutical and Clinical Research. 2012; 5(2):127-131.

18) Joshi S.G. Medicinal plants. Oxford and IBH Publishing Co.Pvt.Ltd. New Delhi.2000.

19) Nudrat Z. Sayed. and Usha Mukundan. Medicinal and aromatic plants of India Part I, Ukaaz Publications, Hyderabad. 2005

20) Azaizeh H., Fulder S., Khalil K., Said O. Ethnomedicinal knowledge of local Arab practitioners in the middle East Region. Fitoterapia. 2003; 74: 98-108. https://doi.org/10.1016/S0367326X(02)00285-X 